\title{
Fatal dissemination of cytomegalovirus after bone marrow transplantation
}

\author{
AW CRAFT, PJ HAMILTON, J McQUillin, DJ SCOTT, W WALKER \\ From the Departments of Child Health, Haematology, Virology, and Pathology, Royal Victoria Infirmary, \\ Newcastle upon Tyne NE1 4LP
}

SUMmaRY The clinical course and necropsy findings are described of an 11-year-old child found to have active cytomegalovirus infection at the time of bone marrow transplantation for acute lymphoblastic leukaemia. Attention is drawn to the presence of primitive mononuclear cells of uncertain origin in the regenerating bone marrow.

Successful transplantation of bone marrow offers the patient with aplastic anaemia, acute leukaemia or severe immunodeficiency disease a real possibility of permanent cure. ${ }^{1}$ Until myelopoiesis and cellular and humoral immunity are established, infection remains a cause of serious morbidity and significant mortality. ${ }^{2}$

In this report we describe the clinical and histological manifestations of a fatal disseminated cytomegalovirus (CMV) infection in a child undergoing allogeneic bone marrow transplantation whilst in second remission from acute lymphoblastic leukaemia. Particular attention is drawn to the presence of unusual primitive cells in the regenerating bone marrow.

\section{Case report}

An 11-year-old girl (blood group A rr, HLA type $\mathbf{A}_{2} \mathbf{A}_{3} \mathbf{B}_{15} \mathbf{B}_{35}$ ) presented with acute non-B, non- $T$, periodic acid-Schiff (PAS) block positive, lymphoblastic leukaemia with an initial peripheral blood count of $\mathrm{Hb} 7.8 \mathrm{~g} / \mathrm{dl}$, white cell count $3.1 \times 10^{9} / 1$ $\left(12 \%\right.$ blast cells) and platelet count $42 \times 10^{9} / 1$. She responded rapidly to a modified ALGB 6801 regimen. ${ }^{3}$ She had occasional oral herpes hominis and mild upper respiratory tract infections during which, on different occasions, pneumococci, streptococci, adeno-, echo- and rhino-virus were isolated. Nearly $2 \frac{1}{2}$ years (133 wk) after diagnosis the leukaemia relapsed in association with a listeria monocytogenes septicaemia. A second remission was induced with vincristine, prednisolone and $\mathrm{L}$-asparaginase, consolidated with high-dose methotrexate and maintained with cytosine arabinoside and thio- guanine. Sixteen weeks later, at a time when no blast cells were detectable in cerebrospinal fluid, bone marrow aspirate or trephine, she was prepared for bone marrow transplantation using her blood group incompatible (B $\left.R_{1} r\right)$ HLA type A B locus identical, mixed lymphocyte culture unreactive 7-year-old sister as the donor. The anti-B titre of the recipient was $1 / 16$ seven days before transplantation and this fell to $1 / 4$ on the day of transplant. An infusion of donor peripheral blood buffy coat was given to the recipient four days before transplant, cyclophosphamide $60 \mathrm{mg} / \mathrm{kg}(1.9 \mathrm{~g})$ being given intravenously on the third and second days before transplant. On the day of transplant, she received 850 rads midline total body irradiation (TBI) delivered over 75 minutes from a 4.5 megavoltage linear accelerator. Transplantation was effected by infusing $4.1 \times 10^{8}$ nucleated marrow cells $/ \mathrm{kg}$ in $495 \mathrm{ml}$ of aspirate over four hours.

During the two weeks before the transplant the child complained of lethargy, anorexia and had a mild fever. No cause was found for this and CMV titres were less than 1/4. Serum taken seven days before transplant was found to have a CMV titre of $1 / 32$ by the complement fixation technique and urine taken five days before transplant was examined by electron-microscopy for CMV inclusions and although none were found, CMV was subsequently grown from this specimen. The antibody titres to CMV and Epstein-Barr virus (EBV) are shown in the Table.

Before and after transplantation the recipient was nursed in a laminar air flow isolation bed, receiving oral miconazole, framycetin and colistin. The day before transplantation Providentia stuartii was grown from the urine and perineum but was not isolated after five days of oral streptomycin, intravenous 
Antibody titres to CMV and EBV before and after transplantation

\begin{tabular}{cccc}
\hline Day & $E B V$ & $E B V / I g M$ & $C M V$ \\
\hline-38 & $1 / 128$ & $<1 / 10$ & $<1 / 4$ \\
-10 & $1 / 320$ & $*$ & $1 / 32$ \\
+12 & $1 / 640$ & $<1 / 10$ & $1 / 16$ \\
\hline
\end{tabular}

*Rheumatoid factor present.

amikacin and carbenicillin. Despite intensive treatment with antibiotics and transfusions of white cells, platelets and red cells, her temperature rose persistently and her clinical condition deteriorated. Eleven days after the transplant she developed rapid shallow breathing and on day 12 , cyanosis; she died 14 days after transplantation. An occasional polymorph and lymphocytes were noted in the pretransfusion early morning blood films on day 12,13 , and 14 after transplant. Hepatic function remained normal throughout. She received no transfusions of blood or blood products in the three months before transplantation. The CMV antibody titre of the donor was less than $1 / 4$ at the time of transplantation and remained at this level three months later.

\section{NECROPSY FINDINGS}

The major abnormal gross findings at necropsy, which was performed within 12 hours of death, were confined to the lungs. These were heavy and deeply congested and on section were of a uniform appearance with much blood-stained frothy fluid exuding from the cut surface which when removed left the lung with a slightly lobulated dark brown appearance. Histological examination of the lungs revealed pulmonary oedema and haemorrhage with numerous prominent hyaline membranes present in alveolar ducts and respiratory bronchioles (Fig. 1). No evidence of Pneumocystis carinii was found but the presence of large alveolar cells containing intranuclear inclusion bodies typical of CMV infection were noted throughout (Fig. 2). Typical CMVinfected cells were also seen as a profuse infiltrate of the submucosa of the small intestine (Fig. 3) but not of the colon. CMV inclusions were also present in islet of Langerhans cells (Fig. 4) and the thyroid follicular epithelium. The liver showed only marked diffuse fatty change. The adrenals, kidneys, and urinary tract did not contain nuclear inclusions. Cytomegalovirus was isolated by post-mortem culture from lungs and trachea but not from brain, kidney, liver, spleen, or faeces. Lymph nodes showed total lymphoid depletion and in the spleen there was almost total loss of the periarteriolar lymphoid sheath. The thymus showed severe atrophy with occasional calcified Hassall's corpuscles. There was no evidence of leukaemia in any of these tissues.

Smears of an immediate post-mortem bone marrow aspirate showed an overwhelming excess of large primitive mononuclear cells (Fig. 5). Such cells had little cytoplasm, their nuclei contained promi nent nucleoli and were occasionally cleft. These cells were PAS- and Sudan Black-negative but some weré positive with the non-specific esterase stain. Erythropoiesis was relatively well represented and a few

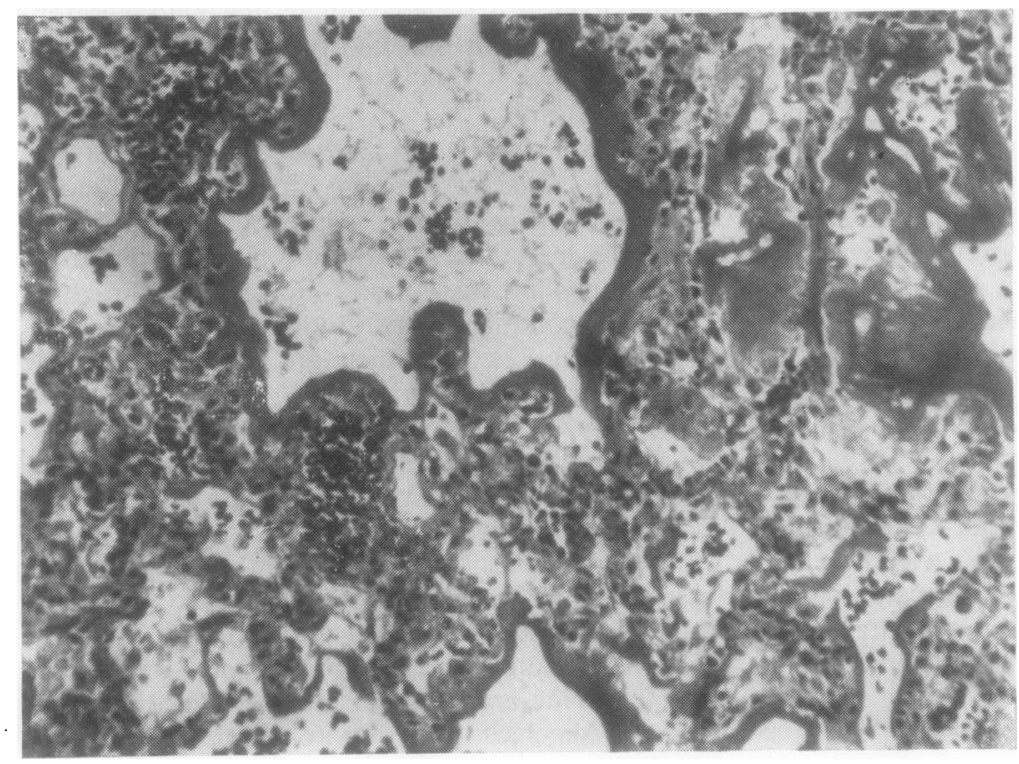

Fig. 1 The lung shows hyaline membranes and interstitial pneumonitis $\times 100$. 


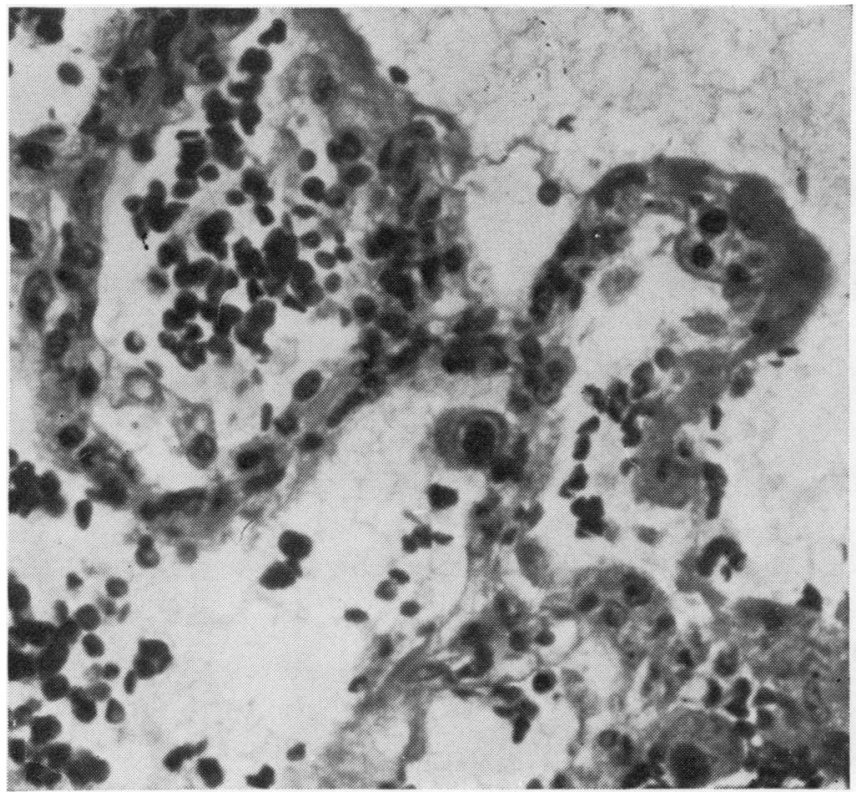

Fig. 2 At higher magnification intranuclear bodies are seen $\times 400$.

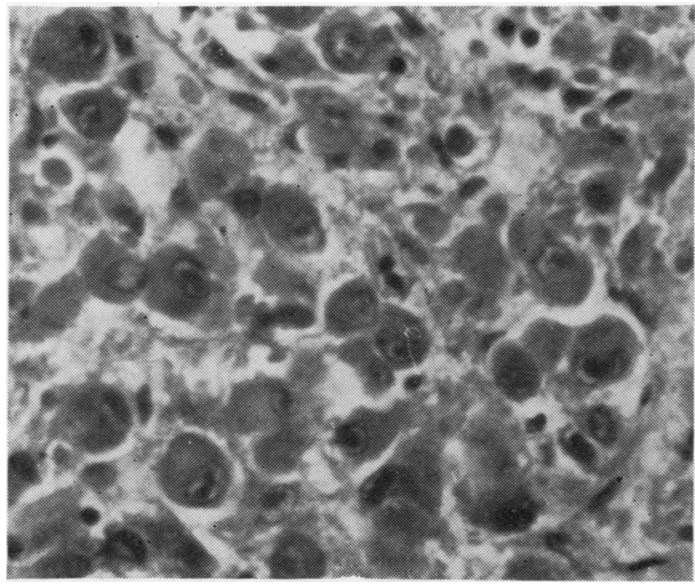

Fig. $3 C M V$-infected cells are present as an infiltrate in the lamina propria of the small bowel $\times 400$.

myeloid forms were noted. Trephine biopsy showed the marrow to be hypocellular with foci of regenerating cells.

\section{Discussion}

There is increasing awareness of the problems of viral infection in the immunologically compromised host. In most previous reports CMV infection was considered to be reactivation of previously acquired infection and often associated with a pneumonitis occurring three to six weeks after transplant ${ }^{4}$ although primary infection acquired from transfusion of whole blood, leucocytes or platelets or the donor marrow are other possibilities. All of these possibilities are unlikely in the present case as she received no transfusions in the immediate pretransplant period and the donor was CMV-negative both before and three months after transplant. In the present case the child had an active primary CMV infection at a time of severe immunosuppression due to previous leukaemia and cytotoxic treatment and this was exacerbated by the pretransplant conditioning. This resulted in the widespread dissemination of the virus shown by the hectic fever and the subsequent demonstration of viral inclusions in such diverse organs as lung, thyroid, pancreatic islets, and small bowel, these being well recognised sites of dissemination in the adult. ${ }^{5}$

The finding of extensive hyaline membrane formation in the lungs is worthy of note. Such appearances have been described as a feature of radiation pneumonitis ${ }^{6}$ and the dose of radiation used here ( $850 \mathrm{rads}$ midline dose given at $22 \mathrm{rad} / \mathrm{min}$ ) has been associated with the development of pneumonitis in about $20 \%$ of patients so treated in Toronto. This problem highlights the question as to what is the optimum dose and delivery rate of TBI required for the successful preparation of patients for marrow transplantation and the avoidance of subsequent pneumonitis. The significance of the rising antibody titre to EBV is also difficult to interpret. The absence 


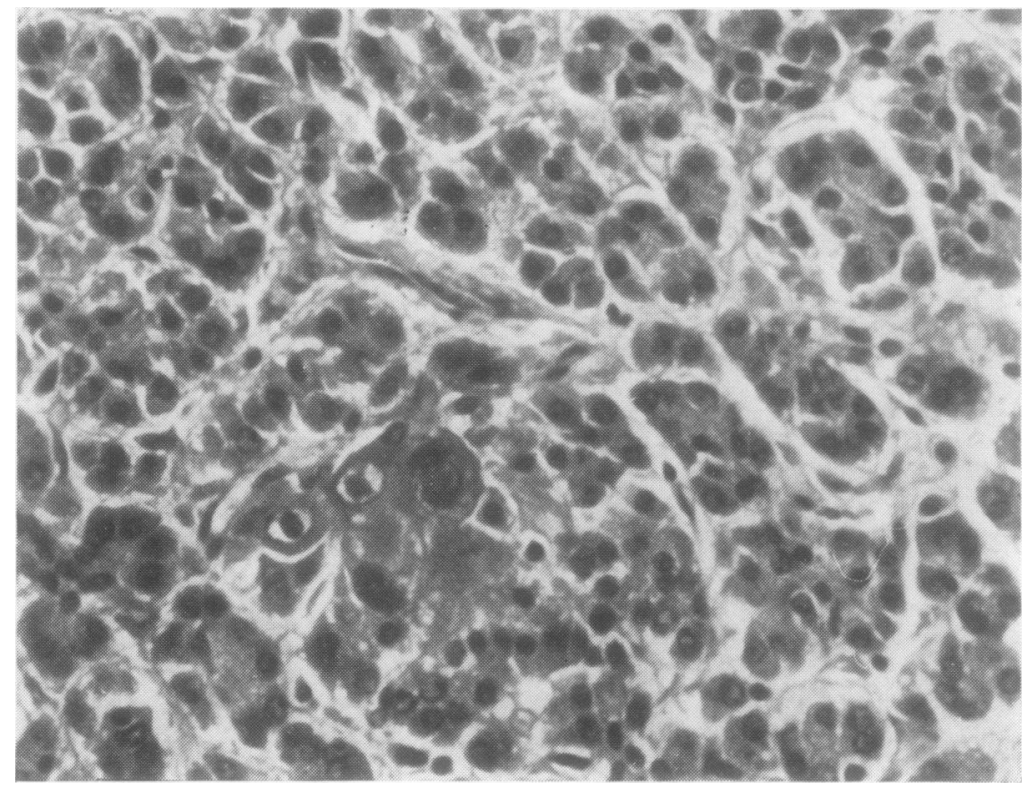

Fig. $4 \quad C M V$ inclusions are preserit in pancreatic islet cells $\times 400$.

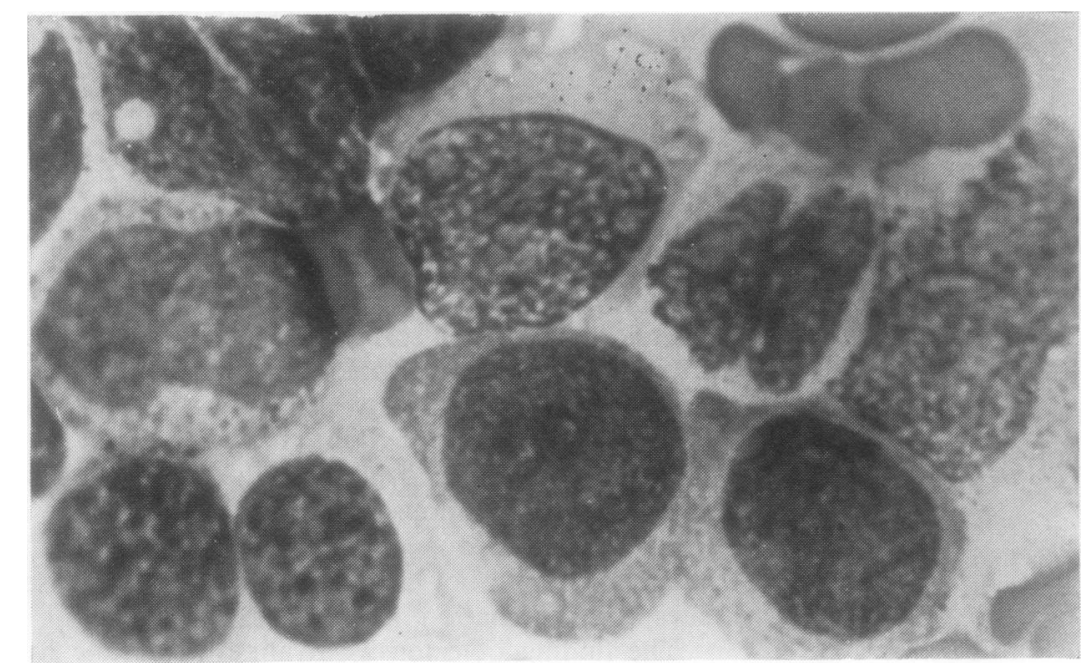

Fig. 5 The bone marrow shows many primitive mononuclear cells $\times 1000$.

of EBV-specific IgM suggests that there was not an active infection at the time of transplantation.

The interpretation of the post-mortem bone marrow aspirate with demonstration of large primitive mononuclear cells remains enigmatic. Such cells are very different morphologically from the original blast cells at presentation and relapse, and the appearance of a new leukaemia as early as the 14th day after transplantation would seem unlikely. Immunoblastic sarcoma has been described after transplantation for acute myeloblastic leukaemia but did not occur until 12 weeks after engraftment. ${ }^{7}$ However, polyclonal lymphomas have been reported as being induced by EBV after renal transplantation and the presence of antibody to EBV in this patient suggests that this may be a possibility here. Such reactions have not been described in association with CMV reactivation. These cells may represent primitive histiocytes or reticuloendothelial cells which were relatively radioresistant and appeared as a response to cell necrosis or the disseminated cytomegalovirus infection, or both. 
The clinical course and outcome of this case demonstrates the need for greater awareness and appreciation of the importance of recognising viral infection in the immunocompromised host and the need for reliable techniques for the rapid diagnosis of CMV infection. This will become even more important when effective antiviral agents become available.

\section{References}

${ }^{1}$ Bone marrow transplantation. Lancet 1978 ;i:859-60.

2 Neiman PE, Thomas ED, Reeves WC, et al. Opportunistic infection and interstitial pneumonia following bone marrow transplantation for aplastic anaemia and haematologic malignancy. Transplant Proc 1976;8: 663-7.

${ }^{3}$ Reid MM, Craft AW, Todd JA. Serial studies of numbers of circulating $T$ and $B$ lymphocytes in children with acute lymphoblastic leukaemia. Arch Dis Child 1977;52: 245-7.

${ }^{4}$ Rinaldo CR, Hirsch MS, Black PH. Activation of latent viruses following bone marrow transplantation. Transplant Proc 1976;8:669-72.

${ }^{5}$ Wong TW, Warner NE. Cytomegalic inclusion disease in adults. Arch Pathol 1962;74:403-22.

- Fryer CJH, Fitzpatrick PJ, Rider WD, Poon P. Radiation pneumonitis: Experience following a large single dose of radiation. Int J Radiat Oncol Biol Phys 1978;4:931-6.

7 Gossett TC, Gale RP, Fleischman H, Austin GE, Sparkes RS, Taylor CR. Immunoblastic sarcoma in donor cells after bone marrow transplantation. $N$ Engl J Med 1979; 300:904-7.

Requests for reprints to: Dr AW Craft, Department of Child Health, Royal Victoria Infirmary, Newcastle upon Tyne NE1 4LP, England.

\section{Reports and Bulletins prepared by the Association of Clinical Biochemists}

The following reports and bulletins are published by the Association of Clinical Biochemists. They may be obtained from The Publishing Department, British Medical Journal (ACB Technical Bulletins), BMA House, Tavistock Square, London WC1H 9JR. Overseas readers should remit by British Postal or Money Order.

SCIENTIFIC REVIEWS (price $£ 1 \cdot 00 / \$ 2.00$ each)

1 The assessment of thyroid function March 1971 FV FLYNN and JR HOBBS

2 Renal function tests suitable for clinical practice January 1972 FL MITCHELL, N VEALL, and RWE WATTS

3 Biochemical tests for the assessment of fetoplacental function May 1975 CE WILDE and RE OAKEY

4 Test of exocrine pancreatic function March 1977 AH GOWENLOCK

5 Assay of cholinesterase in clinical chemistry March 1979 ELSIE SILK, J KING, and MARY WHITTAKER

TECHNICAL BULLETINS (price $£ 1 \cdot 00 / \$ 2.00$ each)

22 Bilirubin standards and the determination of bilirubin by manual and technicon AutoAnalyzer methods January 1971 BARBARA BILLING, RUTH HASLAM, and N WALD

23 Interchangeable cells for spectrophotometers and fluorimeters September 1971 SS BROWN and AH GOWENLOCK

24 Simple tests to detect poisons March 1972 BW MEADE et al.

25 Blood gas analysers May 1972 K DIxON

26 Kits for enzyme activity determination September 1972 SB ROSALKI and D TARLOW

27 Assessment of pumps suitable for incorporation into existing continuous flow analytical systems November 1972 A FLECK et al.

28 Routine clinical measurements of transferrin in human serum September 1973 K DIXON
29 Control materials for clinical biochemistry (5th edition) September 1973 JF STEVENS

30 Notes on the quality of performance of serum cholesterol assays September 1973 SS BROWN

31 Determination of uric acid in blood and in urine July 1974 RWE WATTS

32 A survey of amino acid analysers readily available in the United Kingdom September 1974 JE CARLYLE and P PURKISS

33 Definitions of some words and terms used in automated analysis November 1974 A FLECK, R ROBINSON, SS BROWN, and JR HOBBS

34 Measurement of albumin in the sera of patients January 1975 LINDA SLATER, PM CARTER, and JR HOBBS

35 Investigation of the validity of temperature correction factors for serum aspartate and alanine transaminases March 1975 SB ROSALKI et al.

36 Factors influencing the assay of creatinine November 1975 JGH COOK

37 A survey of enzyme reaction rate analysers readily available in the United Kingdom July 1977 RA SAUNDERS and RF BURNS

38 Transport of specimens for clinical chemistry analysis November 1977 P WILDING, JF ZILVA, and CE WILDE

39 A scheme for the evaluation of diagnostic kits May 1978 PH LLOYD

40 A practical guide to gamma-counting in radioimmunoassay January 1980 CE WILDE and D OTTEWELL 41 The use of biochemical tests in the diagnosis of disorders of calcium metabolism July 1980 ANGELA FAIRNEY 